\title{
Synthesis and Testing of 3-Acetyl-2,5-Disubstituted-2,3-Dihydro-1,3,4-oxadiazole Derivatives for Antifungal Activity Against Selected Candida Species
}

\author{
Cledualdo S. de Oliveira, ${ }^{a}$ Bruno F. Lira, ${ }^{a}$ José M. Barbosa-Filho, ${ }^{b}$ Jorge G. F. Lorenzo, ${ }^{b}$ \\ Camilla P. de Menezes, ${ }^{b}$ Jessyca M. C. G. dos Santos, ${ }^{b}$ Edeltrudes de O. Lima ${ }^{b}$ and \\ Petrônio F. de Athayde-Filho*,a \\ ${ }^{a}$ Departamento de Química, Universidade Federal da Paraíba, 58051-900 João Pessoa-PB, Brazil \\ ${ }^{b}$ Departamento de Ciências Farmacêuticas, Universidade Federal da Paraíba, \\ 58051-900 João Pessoa-PB, Brazil
}

\begin{abstract}
Uma série de 21 derivados, 1,3,4-oxadiazolinas, foi sintetizada pela ciclização de $\mathrm{N}$-acilhidrazonas com anidrido acético e avaliada in vitro quanto à sua atividade antifúngica contra seis espécies de Candida: Candida albicans (ATCC 90028 e LM V-42), Candida krusei (ATCC 6258 e LM 12 C) e Candida tropicalis (ATCC 13803 e LM 14). As espécies de Candida foram consideradas sensíveis a uma série dos compostos, os quais inibiram o crescimento de 50 a $90 \%$, com um intervalo de concentração inibitória mínima (MIC) de 64 a $512 \mu \mathrm{g} \mathrm{mL} \mathrm{mL}^{-1}$. As estruturas dos compostos foram totalmente confirmadas e caracterizadas pelas técnicas de infravermelho com transformada de Fourier (FTIR), ressonância magnética nuclear (NMR) de ${ }^{1} \mathrm{He} \mathrm{e}^{13} \mathrm{C}$, e espectrometria de massa (MS).
\end{abstract}

A series of 21 1,3,4-oxadiazoline derivatives was synthesized by cyclization of $N$-acylhydrazones with acetic anhydride and evaluated for their in vitro antifungal activity against six Candida strains: Candida albicans (ATCC 90028 and LM V-42), C. krusei (ATCC 6258 and LM 12 C) and C. tropicalis (ATCC 13803 and LM 14). The Candida strains were found to be sensitive to some of the compounds, which inhibited the growth by $50-90 \%$, with minimum inhibitory concentration (MIC) in the range of 64-512 $\mu \mathrm{g} \mathrm{mL}^{-1}$. The compounds' structures were fully confirmed and characterized by Fourier transform infrared spectroscopy (FTIR), ${ }^{1} \mathrm{H}$ and ${ }^{13} \mathrm{C}$ nuclear magnetic resonance (NMR) and mass spectrometry (MS).

Keywords: 1,3,4-oxadiazoline, antifungal activity, Candida species, $N$-acylhydrazones

\section{Introduction}

Due to the development of resistant fungous strains and no-longer effective medications, the incidence of systemic fungal infections (with its consequent morbidity and mortality) has been gradually increasing over the last three decades. ${ }^{1}$ The resulting requirement for investigation, research and discovery of new antimicrobial agents that are both safer and more effective is of the utmost importance. Derivatives of 1,3,4-oxadiazoline have recently gained importance (for serving as building blocks) for both organic synthesis and medicinal chemistry when developing new therapeutic agents. It has been noted that compounds containing the 1,3,4-oxadiazoline motif generally exhibit excellent antimicrobial activity. ${ }^{2-12}$

*e-mail: athayde-filho@quimica.ufpb.br
Therefore, taking into consideration our ongoing research and the importance of the 1,3,4-oxadiazoline scaffold as a good source for the discovery of new and biologically active molecules, our group synthesized new 1,3,4-oxadiazoline heterocyclic compounds, (specifically 3-acetyl-2,5-diaryl-2,3-dihydro-1,3,4-oxadiazoles), and pre-screened these compounds for candidacy as novel antifungal agents.

\section{Results and Discussion}

\section{Chemistry}

$N$-acylhydrazones (NAH) belong to the azomethine class of compounds, they are structurally privileged with chemical properties that have proven to be important when designing pharmacologically active prototypes. ${ }^{13,14}$ They are 
particularly versatile for synthesis of compounds containing nitrogen. ${ }^{15}$ With this in mind, it was planned the synthesis of the 1,3,4-oxadiazoline target molecule from the versatile $\mathrm{N}$-acylhydrazone substrate, using the strategy of closing the acyclic chain to give the 1,3,4-oxadiazoline core. The strategy is efficient to obtain the 1,3,4-oxadiazoline target molecule (Figure 1).

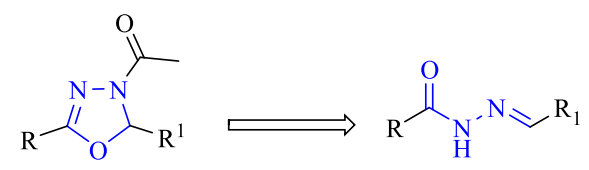

Target molecule 1,3,4-oxadiazolines

$N$-acylhydrazones (NAH), versatile intermediate

Figure 1. Retrosynthetic analysis of 1,3,4-oxadiazoline.

Target molecules $\mathbf{4 a - v}$ were obtained as racemic mixtures in four synthetic steps according to Scheme 1. The $N$-acylhydrazone compounds (3) were obtained from a condensation reaction between acylhydrazides, and aromatic/hetero-aromatic aldehydes according to the literature. ${ }^{2}$ The cyclization reaction of the derivatives (3) with acetic anhydride afforded 1,3,4-oxadiazoline derivatives $\mathbf{4 a - v}$ in yields that were moderate to good (45.4-81.2\%).

Twenty-one 1,3,4-oxadiazoline compounds were synthesized and divided into three congener sets as follows: series 1 (2-aryl-3-acetyl-5-(pyridin-4-yl)-2,3-dihydro1,3,4-oxadiazole, 4a-l), containing the pyridin-4-yl group fixed in 5-position of the 1,3,4-oxadiazoline ring, with varied electron- donating and electron-withdrawing groups linked to the aromatic ring at the 2-position of the core 1,3,4-oxadiazoline, series 2 (2-(4-acetoxyphenyl)-3-acetyl5-aryl-2,3-dihydro-1,3,4-oxadiazole, $\mathbf{4 m - q}$ ), in which the $p$-acetoxyphenyl group remained fixed at the 2-position of the 1,3,4-oxadiazoline ring, and series 3 (2-(5-nitrofuran2-yl)-3-acetyl-5-aryl-2,3-dihydro-1,3,4-oxadiazole, 4r-v) having the group 5-nitrofuran-2-yl fixed at the 2-position of the 1,3,4-oxadiazoline ring. In both series $\mathbf{2}$ and $\mathbf{3}$, electrondonating and electron-withdrawing groups are located at the para position of the aromatic ring and at the 5-position of the 1,3,4-oxadiazoline core, (Figure 2).

Compounds $\mathbf{4 a}, \mathbf{4 c - g}$ and $\mathbf{4 i}$ are known structures. ${ }^{16,17}$ Compounds of series $\mathbf{2}(\mathbf{4 m}-\mathbf{q})$ and compounds $\mathbf{4 b}, \mathbf{4 h}$, $\mathbf{4 j}$ and $\mathbf{4 l}$ are new structures. Compounds of series $\mathbf{3}$ (4r-v) were recently reported by our research group. ${ }^{2}$ The purity of the compounds was verified examining their melting ranges and by gas chromatography (GC-MS) (Table 1). Interestingly, all the compounds contain an acetyl group (which is polar) in the 3-position of the 1,3,4-oxadiazoline core, which gives to these compounds an intermolecular hydrogen bonding site with bio-macromolecules.

\section{Characterization of the final products}

The structures of the compounds were fully characterized and confirmed by using spectroscopic techniques (Fourier transform infrared (FTIR) spectroscospy and ${ }^{1} \mathrm{H}$ and ${ }^{13} \mathrm{C}$ nuclear magnetic resonance (NMR)) and mass spectrometric (MS) studies. The ${ }^{1} \mathrm{H}$ and ${ }^{13} \mathrm{C}$ NMR spectroscopic techniques were sufficient to confirm the formation of the 1,3,4-oxadiazoline ring

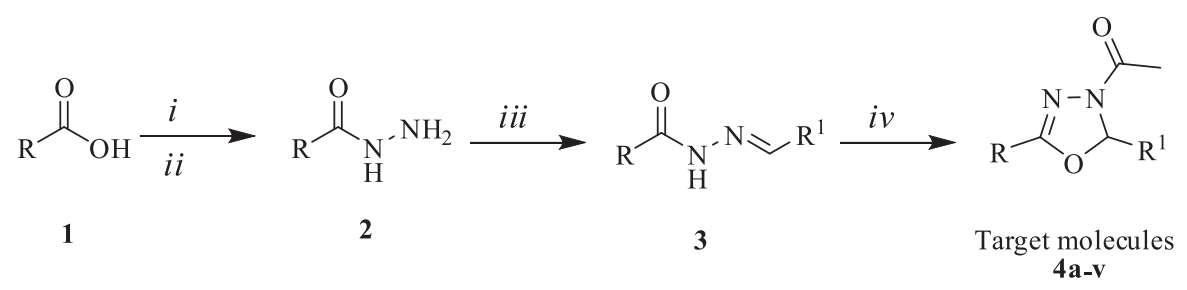

Scheme 1. Reagents and conditions: (i) EtOH, $\mathrm{H}_{2} \mathrm{SO}_{4}(\mathrm{Cat})$, reflux (4 h), (ii) EtOH, hydrazine hydrate, reflux ( $3 \mathrm{~h}$ ), (iii) EtOH, aromatic aldehydes, AcOH (cat.), reflux $(3 \mathrm{~h})$, and (iv) acetic anhydride, reflux $(2 \mathrm{~h})$.

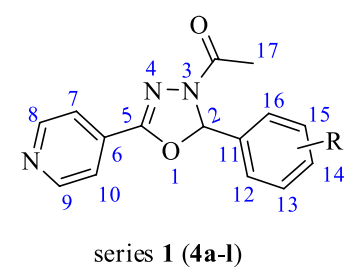

series $1(4 a-1)$

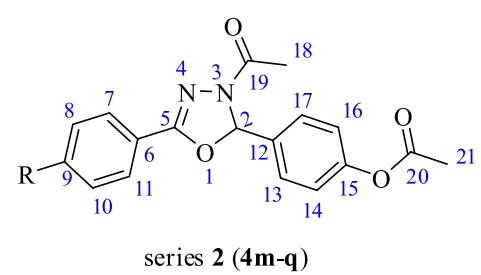

series $2(\mathbf{4 m - q})$

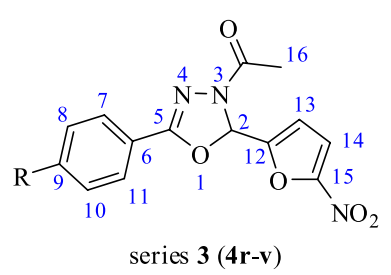

series $3(4 \mathbf{r}-\mathbf{v})$

4a: $\mathrm{R}=\mathrm{Me} ; \mathbf{4 b}: \mathrm{R}={ }^{\mathrm{i}} \mathrm{Pr} ; 4 \mathbf{c}: 4-\mathrm{NO}_{2} ; \mathbf{4 d}: \mathrm{R}=3-\mathrm{NO}_{2} ; \mathbf{4 e}: \mathrm{R}=2-\mathrm{NO}_{2} ; \mathbf{4 f}: \mathrm{R}=4-\mathrm{F} ; \mathbf{4 g}: \mathrm{R}=4-\mathrm{Cl}$;

4h: $\mathrm{R}=4-\mathrm{Br} ; 4 \mathbf{i}: \mathrm{R}=4-\mathrm{OMe} ; \mathbf{4 j}: \mathrm{R}=2,5$-di-OMe; 4l: $\mathrm{R}=4-\mathrm{OAc} ; 4 \mathbf{m}: \mathrm{R}=\mathrm{H} ; \mathbf{4 n}: \mathrm{R}=\mathrm{Me}$;

4o: $\mathrm{R}=\mathrm{NO}_{2} ; \mathbf{4 p}: \mathrm{R}=\mathrm{Cl} ; \mathbf{4 q}: \mathrm{R}=\mathrm{OMe} ; \mathbf{4 r}: \mathrm{R}=\mathrm{H} ; \mathbf{4 s}: \mathrm{R}=\mathrm{Me} ; \mathbf{4 t}: \mathrm{R}=\mathrm{NO}_{2} ; \mathbf{4 u}: \mathrm{R}=\mathrm{Cl} ; \mathbf{4 v}: \mathrm{R}=\mathrm{OMe}$

Figure 2. The chemical structures of the 1,3,4-oxadiazoline compounds. 
Table 1. Physical and chemical properties of novel 1,3,4-oxadiazolines $\mathbf{4 b}, \mathbf{4 h}, \mathbf{4 j}, \mathbf{4 l}$ and $\mathbf{4 m - q}$

\begin{tabular}{|c|c|c|c|c|c|}
\hline \multirow{2}{*}{ Compound } & \multirow{2}{*}{ Molecular formula } & \multirow{2}{*}{ Exact mass } & \multirow{2}{*}{$\mathrm{mp} /{ }^{\circ} \mathrm{C}$} & \multirow{2}{*}{ Yield / \% } & \multirow{2}{*}{$\frac{\text { GC-MS }}{\mathrm{t}_{\mathrm{r}} / \mathrm{min}}$} \\
\hline & & & & & \\
\hline $4 b$ & $\mathrm{C}_{18} \mathrm{H}_{19} \mathrm{~N}_{3} \mathrm{O}_{2}$ & 309.15 & $92-94$ & 66 & 23.4 \\
\hline $4 h$ & $\mathrm{C}_{15} \mathrm{H}_{12} \mathrm{BrN}_{3} \mathrm{O}_{2}$ & 345.01 & $120-121$ & 59 & 24.1 \\
\hline $4 j$ & $\mathrm{C}_{17} \mathrm{H}_{17} \mathrm{~N}_{3} \mathrm{O}_{4}$ & 327.12 & $186-188$ & 57 & 24.3 \\
\hline 41 & $\mathrm{C}_{17} \mathrm{H}_{15} \mathrm{~N}_{3} \mathrm{O}_{4}$ & 325.11 & $162-164$ & 72 & 24.5 \\
\hline $4 m$ & $\mathrm{C}_{18} \mathrm{H}_{16} \mathrm{~N}_{2} \mathrm{O}_{4}$ & 324.11 & $140-141$ & 75 & 24.3 \\
\hline $4 n$ & $\mathrm{C}_{19} \mathrm{H}_{18} \mathrm{~N}_{2} \mathrm{O}_{4}$ & 338.13 & $154-156$ & 70 & 25.3 \\
\hline 40 & $\mathrm{C}_{18} \mathrm{H}_{15} \mathrm{~N}_{3} \mathrm{O}_{6}$ & 369.10 & 192-194 & 64 & 25.8 \\
\hline $4 p$ & $\mathrm{C}_{18} \mathrm{H}_{15} \mathrm{ClN}_{2} \mathrm{O}_{4}$ & 358.07 & $158-160$ & 71 & 25.7 \\
\hline $4 q$ & $\mathrm{C}_{19} \mathrm{H}_{18} \mathrm{~N}_{2} \mathrm{O}_{5}$ & 354.12 & $98-100$ & 45 & 26.5 \\
\hline
\end{tabular}

because of its very characteristic signals. ${ }^{2,17}$ For example, in the ${ }^{1} \mathrm{H}$ NMR spectra of compounds of the series 1 (4a-l), two typical signals were observed, one assigned to the methyl protons of the acetyl group linked to the nitrogen atom N-3 in the aliphatic region of 2.27 to $2.30 \mathrm{ppm}$, and another assigned to methinic protons $\mathrm{H}-2$ in the aromatic region 7.17 to $7.63 \mathrm{ppm}$. In the ${ }^{13} \mathrm{C}$ NMR spectra, signals characteristic of $\mathrm{C}=\mathrm{O}$ around $167 \mathrm{ppm}$, and methyl carbon atom $\mathrm{CH}_{3}$ in the range of 20.1-22.7 ppm, as well as the oxadiazole ring signal C-2 around 88.7 to $92.9 \mathrm{ppm}$, and C-5 around 152.5 to $163.4 \mathrm{ppm}$ were observed, thus confirming its formation.

In the 1-(2-(4-fluorophenyl)-5-(pyridin-4-yl)1,3,4-oxadiazol-3(2H)-yl)ethanone, (4f) spectrum, it was observed doublets corresponding to couplings ${ }^{13} \mathrm{C}-{ }^{19} \mathrm{~F}$, whose coupling constants for one bond ${ }^{1} J_{\mathrm{CF}} 245.0 \mathrm{~Hz}$, two bonds ${ }^{2} J_{\mathrm{CF}} 32.0 \mathrm{~Hz}$ and three bonds ${ }^{3} J_{\mathrm{CF}} 9.0 \mathrm{~Hz}$ were assigned respectively to couplings C-F in $\delta 162.4$ (C-14), $\delta 115.4$ $(\mathrm{C}-11,15)$ and $\delta 128.8(\mathrm{C}-12,16) \mathrm{ppm}$. In the ${ }^{1} \mathrm{H}$ NMR spectra for series $\mathbf{2}(\mathbf{4 m}-\mathbf{q})$ compounds, it was observed the characteristic signals: a singlet for hydrogen 3 (acetyl group linked to nitrogen (N-3)) in the aliphatic region of 2.25 to $2.27 \mathrm{ppm}$, a singlet for hydrogen 3 (acetoxy group linked to the benzene ring) in the aliphatic region of ( 2.26 to $2.30 \mathrm{ppm}$ ), and singlet for hydrogen $1(\mathrm{H}-2)$ in the aromatic region of 7.17 to $7.26 \mathrm{ppm}$. In the ${ }^{13} \mathrm{C}$ NMR spectra, the characteristic signals observed were: two carbon atoms of the 1,3,4-oxadiazoline core (C-2 and C-5) in the regions of 91.0 to $92.3 \mathrm{ppm}$ and 153.2 to $154.7 \mathrm{ppm}$, respectively. The chemical shifts of $\mathrm{C}=\mathrm{O}$ of the acetyl group linked to nitrogen atom $(\mathrm{N}-3)$, and the $\mathrm{C}=\mathrm{O}$ of the acetoxy group were observed in the range of 166.6 to $167.2 \mathrm{ppm}$ and 168.8 to $169.2 \mathrm{ppm}$, respectively. The characterization of series 3 (4 r-v) compounds was recently reported by our group. ${ }^{2}$

In the infrared spectrum, compounds $\mathbf{4 a - q}$ showed amide $\mathrm{C}=\mathrm{O}$ absorption bands from 1662 to $1674 \mathrm{~cm}^{-1}$,
C-O-C absorption stretches (oxadiazole ring) from 1095 to $1240 \mathrm{~cm}^{-1}$, and $\mathrm{C}=\mathrm{N}$ absorptions (oxadiazole ring) from 1604 to $1635 \mathrm{~cm}^{-1}$. The compound 4-(3-acetyl-5-(pyridin4-yl)-2,3-dihydro-1,3,4-oxadiazol-2-yl)phenyl acetate 4I and all compounds of series $2(\mathbf{4 m}-\mathbf{q})$ also showed absorption bands in the 1755 to $1759 \mathrm{~cm}^{-1}$ range for $\mathrm{C}=\mathrm{O}$ (acetoxy group).

The fragmentation most observed in the mass spectra of the new compounds ( $\mathbf{4 b}, \mathbf{4 g}, \mathbf{4 j}, \mathbf{4 l}$ and $\mathbf{4 m}-\mathbf{q}$ ) is exemplified by compound $\mathbf{4 l}$. In the mass spectrum of compound $\mathbf{4 l}$, it was not detected a peak related to the molecular ion $(\mathrm{m} / \mathrm{z}, 325)$, this due to the presence of an acetyl radical which easily promotes the loss of one ketene molecule, and the transfer of a hydrogen to form a phenol. However, the radical cation $(\mathrm{m} / \mathrm{z}, 283)$ originating from the first breaking of the molecular ion, and corresponding to the elimination of a neutral ketene, was not observed. The peak at $\mathrm{m} / \mathrm{z} 241$ originates from the radical cation $(\mathrm{m} / \mathrm{z} 283)$ through loss of a second neutral ketene molecule. The base peak was assigned to the acylium ion $(\mathrm{m} / \mathrm{z}, 43)$. In Scheme 2, it is outlined a fragmentation pattern proposal for that observed in the mass spectrum of compound $\mathbf{4 l}$.

\section{Antifungal activity}

The in vitro antifungal activity of compounds $4 \mathrm{a}-\mathrm{v}$ was evaluated by the microdilution method against six strains of pathogenic fungi, Candida albicans (ATCC 90028 and LM V-42), Candida krusei (ATCC 6258 and LM 12 C) and Candida tropicalis (ATCC 13803 and LM 14), using nystatin as the drug standard (Table 2). The compounds were tested at concentrations from 32 to $1024 \mu \mathrm{g} \mathrm{mL}^{-1}$, and solubilized in dimethylsulfoxide, DMSO (Sigma Chemical) to $10 \%$ to avoid interferences with the microorganisms. The antifungal activity of the products was interpreted, and considered active or not, according to the following 


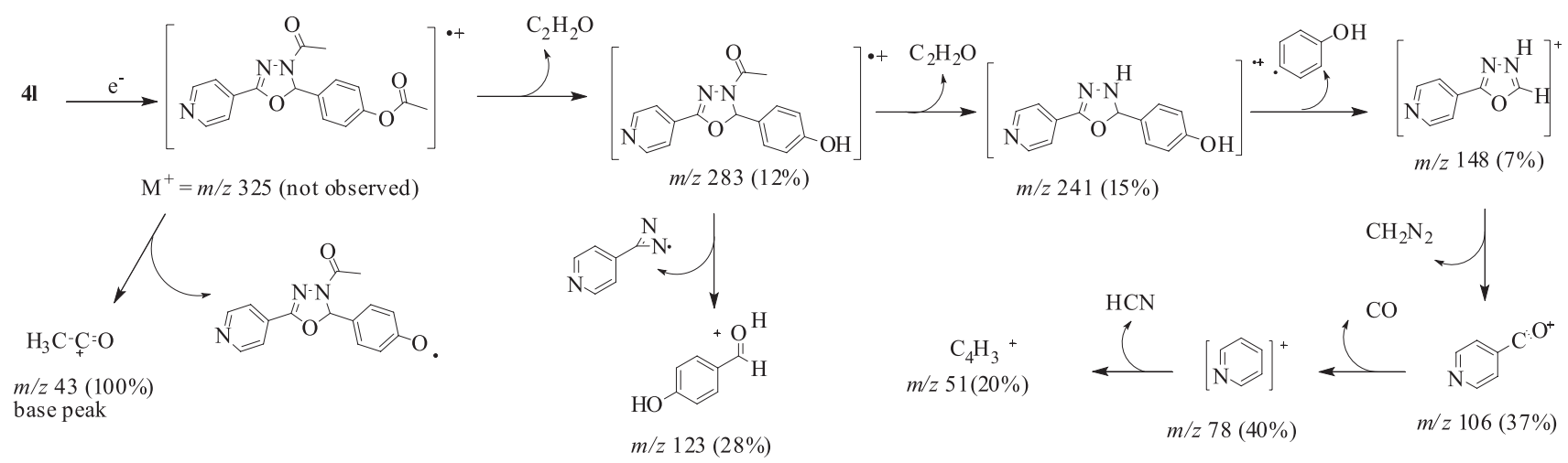

Scheme 2. Fragmentation pattern proposal for the compound $\mathbf{4 1}$.

Table 2. Antifungal activity of 1,3,4-oxadiazoline $\mathbf{4 m - q}$ and $\mathbf{4 r - v}$

\begin{tabular}{|c|c|c|c|c|c|c|}
\hline \multirow{3}{*}{ Compounds } & \multicolumn{6}{|c|}{ Minimum inhibitory concentration (MIC) / $\left(\mu \mathrm{g} \mathrm{mL}^{-1}\right)$} \\
\hline & \multicolumn{6}{|c|}{ Candida Strains } \\
\hline & $\begin{array}{c}\text { C. albicans } \\
\text { ATCC } 90028\end{array}$ & $\begin{array}{l}\text { C. albicans } \\
\text { LM V-42 }\end{array}$ & $\begin{array}{c}\text { C. krusei } \\
\text { ATCC } 6258\end{array}$ & $\begin{array}{l}\text { C. krusei } \\
\text { LM 12C }\end{array}$ & $\begin{array}{l}\text { C. topicalis } \\
\text { ATCC } 13803\end{array}$ & $\begin{array}{l}\text { C. topicalis } \\
\text { LM } 14\end{array}$ \\
\hline $4 m$ & $\mathrm{R}$ & 1024 & $\mathrm{R}$ & 1024 & $\mathrm{R}$ & $\mathrm{R}$ \\
\hline $4 n$ & $\mathrm{R}$ & 128 & 128 & $\mathrm{R}$ & $\mathrm{R}$ & $\mathrm{R}$ \\
\hline 40 & $\mathrm{R}$ & $\mathrm{R}$ & $\mathrm{R}$ & $\mathrm{R}$ & $\mathrm{R}$ & $\mathrm{R}$ \\
\hline $4 p$ & $\mathrm{R}$ & $\mathrm{R}$ & $\mathrm{R}$ & $\mathrm{R}$ & $\mathrm{R}$ & $\mathrm{R}$ \\
\hline $4 q$ & $\mathrm{R}$ & $\mathrm{R}$ & $\mathrm{R}$ & $\mathrm{R}$ & $\mathrm{R}$ & $\mathrm{R}$ \\
\hline $4 r$ & 64 & 64 & 256 & $\mathrm{R}$ & 512 & 512 \\
\hline $4 s$ & 128 & 128 & 128 & $\mathrm{R}$ & $\mathrm{R}$ & 128 \\
\hline $4 t$ & 128 & $\mathrm{R}$ & 256 & $\mathrm{R}$ & $\mathrm{R}$ & 256 \\
\hline $4 u$ & 512 & 128 & 128 & $\mathrm{R}$ & $\mathrm{R}$ & 64 \\
\hline $4 v$ & 64 & 128 & 64 & $\mathrm{R}$ & 128 & 128 \\
\hline Control yeast & + & + & + & + & + & + \\
\hline Nystatin & - & - & - & + & + & - \\
\hline
\end{tabular}

R: resistant; +: growth of the microorganism; -: no growth of the microorganism.

parameters: $50-100 \mu \mathrm{g} \mathrm{mL}-1=$ good activity; $100-$ $500 \mu \mathrm{g} \mathrm{mL}^{-1}=$ moderate activity; $500-1000 \mu \mathrm{g} \mathrm{mL}^{-1}=$ low activity; greater than $1000 \mu \mathrm{g} \mathrm{mL}{ }^{-1}=$ inactive product. ${ }^{18}$

From the 21 compounds tested, compounds $\mathbf{4 a - m}$ and 4o-q showed no inhibitory activity against the mentioned yeasts in the bioassays. Compound $4 \mathrm{n}$ showed moderate inhibitory effect against Candida albicans (LM V-42), and Candida krusei (ATCC 6258) at a minimum concentration of $128 \mu \mathrm{g} \mathrm{mL}^{-1}$. The Candida species were sensitive to compounds of series $3(\mathbf{4 r}-\mathbf{v})$, these compounds inhibited the growth by 50 to $90 \%$ (MIC range of 64-512 $\mu \mathrm{g} \mathrm{mL}^{-1}$ ). The best results were against Candida albicans (ATCC 90028) exhibited by compounds $4 \mathbf{r}$ and $\mathbf{4 v}$ with an MIC of $64 \mu \mathrm{g}$ $\mathrm{mL}^{-1}$, while compounds $4 \mathbf{u}$ and $\mathbf{4 v}$ exhibited the best results against Candida krusei, and Candida tropicalis with an MIC of $64 \mu \mathrm{g} \mathrm{mL}^{-1}$, respectively. Candida krusei (LM 12C) showed no sensitivity to any of the tested compounds. The standard drug, nystatin at $100 \mathrm{IU} \mathrm{mL}^{-1}$ inhibited the growth of four (67\%) of the Candida strains. The results therefore were considered between good and moderate in terms of biological activity, and taking into account the parameters established. ${ }^{18}$ The results show that compounds $4 \mathbf{r}-\mathbf{v}$ may be considered promising for possible development of new antifungal agents, and, that the 5-nitrofuranyl group in these compounds is important for their activity.

\section{Conclusions}

In this work, it was synthesized a series of twenty-one 1,3,4-oxadiazoline compounds, and their structures were confirmed by the techniques FTIR ${ }^{1} \mathrm{H}$ and ${ }^{13} \mathrm{C}$ NMR and MS. For in vitro antifungal activity against Candida strains, compounds $\mathbf{4 r - v}$ showed good to moderate activity, inhibiting the growth of the strains used by 
$50-90 \%$ with an MIC of $64-512 \mu \mathrm{g} \mathrm{mL}^{-1}$. These may be promising compounds for the development of new antifungal agents.

\section{Experimental}

\section{Chemistry}

All used reagents and solvents were purchased from commercial sources (Sigma-Aldrich, Brazil), and used without a further purification. The purification of the compounds was performed by re-crystallization in ethanol, and confirmed by determining the melting range on an MQAPF-3 hotplate, and by gas chromatography with low resolution mass spectrometer (GC-MS-QP2010) Shimadzu. The FTIR spectra were obtained on an FTIR spectrometer model IRPrestige-21-Shimadzu, using $\mathrm{KBr}$ pellets. ${ }^{1} \mathrm{H}$ and ${ }^{13} \mathrm{C}$ NMR spectra were obtained on two different machines: a Varian $200 \mathrm{NMR}$ (200 and $50 \mathrm{MHz}$ for ${ }^{1} \mathrm{H}$ and for ${ }^{13} \mathrm{C}$, respectively), and a Varian $500 \mathrm{NMR}$ (500 and $125 \mathrm{MHz}$ for ${ }^{1} \mathrm{H}$ and ${ }^{13} \mathrm{C}$, respectively), deuterated dimethyl sulphoxide (DMSO- $d_{6}$ ) was used as the solvent and tetramethylsilane (TMS) was used for the internal standard. Chemical shifts $(\delta)$ were measured in parts per million (ppm) and the coupling constants $(J)$ in $\mathrm{Hz}$.

\section{Antifungal activity}

\section{Microorganisms}

The microbiological assays used: Candida albicans (ATCC 90028 and LM V-42), C. krusei (ATCC 6258 and LM 12 C) and C. tropicalis (ATCC 13803 and LM 14). The strains were acquired from the Institute Adolfo Lutz of São Paulo and Mycology Laboratories of the Departments of Pharmaceutical Sciences at the University of Sao Paulo and the Federal University of Paraiba, respectively. The fungal strains were maintained in appropriate medium, Sabouraud Dextrose Broth-SDB (DIFCO Laboratories, France-USA), and stored at $4{ }^{\circ} \mathrm{C}$ and $35{ }^{\circ} \mathrm{C}$. The suspension of microorganisms was prepared according to the $0.5 \mathrm{McF}$ arland scale tube, and adjusted by means of a spectrophotometer (Leitz-Photometer 340-800) to $90 \% \mathrm{~T}(530 \mathrm{~nm})$ corresponding to approximately $10^{6} \mathrm{UFC} \mathrm{mL}{ }^{-1} \cdot{ }^{19-21}$

\section{Culture medium}

The antifungal activity assays were performed in Sabouraud Dextrose Broth-SDB (DIFCO Laboratories, France-USA), which was prepared and used according to manufacturer instructions.
Determination of minimum inhibitory concentration (MIC)

The MIC value was determined by the microdilution method, using 96 well microtiter plates with background in a " $U$ " and in duplicate. To each well of the plate, it was added $100 \mu \mathrm{L}$ of liquid medium SDB doubly concentrated. Then, $100 \mu \mathrm{L}$ of the product solution (also doubly concentrated) were dispensed into the wells of the first line of the plate. By means of serial dilution (ratio of two), it was obtained concentrations from 2,048 to $64 \mu \mathrm{g} \mathrm{mL} \mathrm{m}^{-1}$, so that in the first row of the plate, the highest concentration, and in the latter, the lower concentrations. Finally, $10 \mu \mathrm{L}$ of inoculum were added to the wells where each column of the plate referred specifically to a strain. The same was also done in the culture medium with fungal drug nystatin (100 UI). The plates were incubated at $37{ }^{\circ} \mathrm{C}$ for $24-48 \mathrm{~h}$. For each strain, MIC was defined as the lowest concentration able to inhibit fungal growth visually observed in the wells, when compared to the control. All tests were performed in duplicate, and the results were expressed as the geometric mean of the MIC values obtained in the two trials. ${ }^{21-23}$

\section{Acknowledgments}

This work was supported by the following Brazilian agencies: Conselho Nacional de Desenvolvimento Científico e Tecnológico (CNPq) and Coordenação de Aperfeiçoamento de Pessoal de Nível Superior (CAPES). The English in this article was reviewed by David Peter Harding.

\section{Supplementary Information}

Supplementary information is available free of charge at http://jbcs.sbq.org.br as PDF file.

\section{References}

1. Scotti, L.; Scotti, M. T.; Lima, E. O.; Silva, M. S.; Lima, M. C. A.; Pitta, I. R.; Moura, R. O.; Oliveira, J. G.B.; Cruz, R. M. D.; Mendonça Jr., F. J. B.; Molecules 2012, 17, 2298.

2. Oliveira, C. S.; Lira, B. F.; Falcão-Silva, V. S.; Siqueira-Junior, J. P.; Barbosa-Filho, J. M.; Athayde-Filho, P. F.; Molecules 2012, 17, 5095 .

3. Sahin, G.; Palaska, E.; Ekizoglu, M.; Ozalp, M.; Il Farmaco 2002, 57, 539.

4. Fuloria, N. K.; Singh, V.; Shaharyar, M.; Ali, M.; Molecules 2009, 14, 1898.

5. Kumar, S.; J. Chil. Chem. Soc. 2010, 55, 126.

6. Sangshetti, J. N.; Chabukswar, A. R.; Shinde, D. B.; Bioorg. Med. Chem. Lett. 2011, 21, 444.

7. Chandrakantha, B.; Shetty, P.; Nambiyar, V.; Isloor, N.; Isloor, A. M.; Eur. J. Med. Chem. 2010, 45, 1206. 
8. Bakht, M. A.; Yar, M. S.; Abdel-Hamid, S. G.; Qasoumi, S. I.; Samad, A.; Eur. J. Med. Chem. 2010, 45, 5862.

9. Kumar, R.; Kumar, A.; Jain, S.; Kaushik, D.; Eur. J. Med. Chem. 2011, 46, 3543.

10. Li, Z.; Zhu, A.; Mao, X.; Sun, X.; Gong, X.; J. Braz. Chem. Soc. 2008, 19, 1622.

11. Savariz, F. C.; Formagio, A. S. N.; Barbosa, V. A.; Foglio, M. A.; Carvalho, J. E.; Duarte, M. C. T.; Filho, B. P. D.; Sarragiotto, M. H.; J. Braz. Chem. Soc. 2010, 21, 288.

12. Oliveira, C. S.; Lira, B. F.; Barbosa-Filho, J. M.; Lorenzo, J. G. F.; Athayde-Filho, P. F.; Molecules 2012, 17, 5095.

13. Silva, Y. K. C.; Augusto, C. V.; Barbosa, M. L. C.; Melo, G. M.A.; Queiroz, A. C. Dias, T. L. M. F.; Júnior, W. B.; Barreiro, E. J.; Lima, L. M.; Moreira, M. S. A.; Bioorg. Med. Chem. 2010, $18,5007$.

14. Rollas, S.; Küçükgüzel. S. G.; Molecules 2007, 12, 1910.

15. Sugiura, M.; Kobayashi, S.; Angew. Chem., Int. Ed. 2005, 44, 5176.
16. Maccioni, E.; Alcaro, S.; Cirilli, R.; Vigo, S.; Cardia, M. C.; Sanna, M. L.; Meleddu, R.; Yanez, M.; Costa, G.; Casu, L.; Matyus, P.; Distinto, S.; J. Med. Chem. 2011, 54, 6394.

17. Cerioni, G.; Maccioni, E.; Cardia, M. C.; Vigo, S.; Mocci, F.; Magn. Reson. Chem. 2009, 47, 727.

18. Holetz, F. B.; Howes, M. J.; Lee, C. C.; Steventon, G.; Mem. Inst. Oswaldo Cruz. 2002, 97, 1027.

19. National Committee for Clinical and Laboratory Standards (NCCLS); Performance Standards for Antimicrobial Disk Susceptibility Tests, $7^{\text {th }}$ ed.; NCCLS: Villanova, PA, 2000.

20. Hadacek, F. Greger, H.; Phytochem. Anal. 2000, 11, 137.

21. Cleland, R.; Squires, E. In Lorian, V. M. D.; Willians \& Wilkins: Baltimore, USA, 1991, p. 739.

22. Eloff, J. N.; Planta Med. 1978, 64, 711.

23. Souza, E. L.; Stamford, T. L. M.; Lima, E. O.; Trajano, V. N.; Food Control, 2007, 18, 409.

Submitted: August 25, 2012 Published online: February 18, 2013 